\title{
Measuring Bank Efficiency: Evidence from the Tanzanian Banking Sector
}

\author{
Zawadi Ally ${ }^{1}$, Dr. G.N. Patel ${ }^{2}$ \\ ${ }^{1}$ Assistant Lecturer Institute of Finance Management (IFM) \\ Shaaban Robert Street \\ P.O. Box 3918, Dar es Salaam, Tanzania \\ Email:zawally2001@yahoo.com \\ ${ }^{2}$ Professor Birla Institute of Management Technology
}

Plot No. 5, Knowledge Park- II, Institutional Area Greater Noida, India - 201306

Email: gn.patel@bimtech.ac.in

\begin{abstract}
The objective of this study is to measure the efficiency of commercial banks in Tanzania using a non-parametric approach, the input-oriented data envelopment analysis (DEA), both by constant return to scale (CRS) and variable return to scale (VRS). For this purpose, two outputs representing total loans and total interest income, and three inputs representing total deposits, the number of employees and total expenses are selected for seven-years (20062012) period in the analysis. The findings under CRS model identify four banks to be fully efficient in the year 2006 , two banks in 2007 and one bank in 2008, 2009, 2010, 2011 and 2012, while VRS model results identify five banks to be fully efficient in the year 2006 and 2012, three banks in 2007 and two banks in 2008 and 2009, one bank 2010 and 2011. Four banks, Standard Charted bank, National Commercial Bank (NBC), Citibank and Barclays bank are found to be the most efficiency banks in Tanzania, which serve as the benchmark peers for inefficient banks in the sample, In addition Tobit regression has been used to determine the efficiency drivers
\end{abstract}

Keywords: Bank efficiency, Financial Sector in Tanzania, Data Envelopment Analysis, Tobit regression

\section{Council for Innovative Research}

Peer Review Research Publishing System

Journal: International Journal of Management \& Information Technology

Vol. 8, No. 1

editor@cirworld.com

www.cirworld.com, member.cirworld.com 


\subsection{INTRODUCTION}

The importance of efficiency evaluation in the financial sector is related to the extremely extensive impact that an efficient financial system has on the microeconomic as well as macroeconomic level. Financial sector deeply affects the allocation of financial resources, helping to find their best productive employment in the most effective way, reducing misallocation and unnecessary wastes (Zuzana, 2009). In order to properly allocate the economic resources, the financial sector, banks included needs to be efficient. Efficiency in banking sector supports the fruitfulness of implemented macroeconomic policies, generating durable development, economic growth and welfare. Recent trends in the market development of the banking sector include the growing demand for banking services and financial activities on the large international scale, cumulative impact of the fast technological development, and decrease in regulation of the sector and interventions but also an increasing competition on the market (Zuzana, 2009). The regulatory weakening gave a starting point to the emergence of acquisitions and mergers, creating larger institutions utilizing the scaling effect especially on the cost level. On the other hand, banks striking against wider competition face a decrease in average profits. Bank management is therefore struggling for an enhancement of efficiency, while regulators and lawmakers have to ascertain the efficiency before globalization of the market. Banks have to design their strategic moves with respect to many variables to survive, prosper and be rewarding, so that their politics and interests involve interests of the regulators, lawmakers, supervisory and antitrust agencies. Both managers and external decision/law-makers need to have the accurate information about the effects of their acts on performance of these institutions (Zuzana, 2009).

In developing countries, banks play a major role in financial development, this is especially true since stock and corporate bond markets are usually underdeveloped. Moreover, the development of the banking system and the increase of its efficiency are related to higher economic growth. Determining banking efficiency would enable bank's management to identify areas of efficiency and/or inefficiency in comparison to their competitors. Such recognition indeed helps the banks' management to improve its performance and market position. Efficiency estimate captures also the effects of deregulation and financial disruption, institutional failure, problem loans, management quality, market concentration, and the mergers and acquisitions. Thus, the enhanced efficiency in banks contributes to a healthier economy. This is because the banking sector output is highly correlated with economic growth (Berger and Humphrey, 1997).

Efficiency of banking sector in Tanzania is important and should receive greater attention; its efficiency will indirectly affect the whole country's economics, operation and wealth. The efficiency analysis of banks in Tanzania would benefit the managerial and administrative personnel a lot in that they could have a clear understanding of their status in the national and international banking industry and the gap between their own banks and other banks through the analysis so as to adopt the measures with a clear aim and what is more, improve management and administration and realize sustainable development.

Therefore, the objective of the study is to evaluate the efficiency of large commercial banks in Tanzania for seven years from the period of 2006 to 2012 using CCR and BCC models of DEA, in addition Tobit regression model has been used to determine the efficiency drivers. The motivation behind this objective is the fact that, evaluating banks efficiency would enable to identify the suitable policies and strategies for increasing banks efficiency, so that they will be able to fully play their role of financial intermediary in the country. The present study is different from previous studies by employing various efficiency measures to evaluate the soundness and efficiency of banks and draw a more complete picture for the Tanzanian banking sector by providing valuable information from different perspectives of banks efficiency.

The rest of the paper is organized as follows. The next section provides a summary review of literature. Section three describes the methodology of the study. Section four discusses the results of the findings and analysis; while section five concludes the discussion.

\subsection{The Structure of the Tanzanian Banking System}

The financial sector in Tanzania has undergone substantial structural change since the liberalization of the sector in 1991. The financial landscape in Tanzania is comprised of mainly banks, pension funds, insurance companies, and other financial intermediaries. However, the sector is dominated by banking institutions which account for about 75 percent of the total assets of the financial system, followed by pension funds whose assets account for about 21 percent and the insurance sector with 2.0 percent of the total assets, while the remaining financial intermediaries hold about 2 percent (Bank of Tanzania, 2011). The sector is made up of 45 banking institutions. The banks hold a combined $75 \%$ market share of total financial sector assets (European Investment Banks, 2013). 93.3\% of banking sector in Tanzania is commercial banks. Commercial banks in the country can be sub divided into three major categories: Large domestic bank; subsidiaries of major international banks; and small banks including domestic and foreign banks. Subsidiaries of the major international banks hold 40 percent; small banks hold $10 \%$ of the total assets of the banking sector. By considering ownership, most commercial banks in Tanzania are foreign. Some commercial banks have taken serious initiatives in investing in microfinance institutions. Bank of Tanzania has put in place 
microfinance regulations s so as to encourage the microfinance institutions and banks to invest in this virgin area. This has increased outreach of financial services in rural areas, which has been affected by financial transformation and reforms this is due to the fact that some bank branches in rural areas were closed (Bank of Tanzania, 2011)

\subsection{Literature review}

The term "efficiency" is one of the key concepts for financial institutions. It has been extensively studied due to its importance. Mainly, the studies making typical comparisons of bank performance can be divided into two categories: (1) those which use simple aggregate bank ratios relating cost to revenues or assets, and (2) frontier technique which measures a bank's efficiency by its distance to the efficient frontier. In this paper we will use the particular frontier technique of Data Envelopment Analysis (DEA) to analyze the efficiency of large commercial banks in Tanzanian banking system.

\subsection{Empirical literature review on bank efficiency}

In recent years banking efficiency has become a major research topic and more study has been conducted, to investigate the reasons and sources of banks' inefficiency. Well established efficiency literature has been mainly carried out in developed nations like the US and European countries.. Berger and Humphrey (1997) provide a valuable summary on 130 studies of financial sector efficiency in 21 countries during different time periods using different estimation techniques. In their studies, they find that results from various efficiency methods are inconsistent. Later on, Bauer et al. (1998) propose a set of consistency conditions by comparing different frontier efficiency methods with a purpose of regulatory analysis. Berger et al. (1993) expanded the Norwegian study to an international comparison, by including Finish and Swedish banking industries. In their study assessed and making the comparison of the X-efficiencies among three different countries' banks. They estimated the efficiency of banks within each country by employing of DEA approach. The results of the study indicated that, Swedish banks were more efficient than other two countries. Wu (2007), examined the efficiency and productivity performance of Australian banking sector during the post-deregulation period of 1983 to 2001 by employing data envelopment analysis and Malmquist productivity index, the results of the study showed that, major banks and existing regional banks were found to be the least and the second least efficient groups, respectively while foreign banks and newly licensed regional banks showed superior performance. Pastor at el (1997) employed non- parametric approach (DEA) by using three outputs (loans, other productive assets, and deposits) and two inputs (non-interest expenses and personal expenses), comparing the productivity, efficiency, and differences in the technology of different in European and U.S. banking sector for the year 1992. The results of the study found that there was a difference in the efficiency level of the banking systems among the countries in the sample, the results showed that, the most efficient banks were in France, Spain, and Belgium, while the less efficient banks were in the U.K., Austria, and Germany. Grabowski et al (1993) examined the US multi-bank holding companies and branching banks by using Data Envelopment Analysis (DEA) approach, the results of the study found that, on average input inefficiency of the US multi-bank holding companies and branching banks was about 68\%. Supachet (2008) employed Data Envelopment Analysis to analyze Relative efficiency of commercial banks in Thailand, using production approach the study used interest expenses, labor related expenses and capital related expenses as input variables and interest income and dividend income as output variables, while in intermediation approach the study used total deposits and total expenses as input variables, loans and net investments as output variables ,the findings of the study revealed that, the efficiency of Thai commercial banks via production approach was very high and stable while using intermediation approach the performance was moderately high and volatile. When referring to size, large medium and small, small banks were efficient via operational approach with average efficiency of $100 \%$. The similar study was used to compare the efficiency status of Foreign and Domestic banks in Malaysia, the study by Theng and Heng (2011) applied Data Envelopment Analysis to compare the efficiency of Domestic and foreign banks in Malaysia. Frimpong (2010) examined the relative efficiency of the banks in Ghana during the year 2007, which investigates the efficiency and profitability linkage by employed Data envelopment analysis (DEA) approach with Intermediation Model InputOutput Specification with 3 state-owned sector banks, 8 private domestic banks and 11 foreign banks. He found only four (out of 22) banks were efficient and 18 inefficient banks had their efficiencies ranging from $33 \%$ to $89 \%$. The average technical efficiency for the banking sector was $74 \%$ a, the Domestic private banks were the most efficient group of banks in Ghana, their average efficiency level being $87 \%$, followed by foreign banks average of $72 \%$ and lastly, the state-owned banks with an average score of only $51 \%$. Kiyota (2009) provide a comprehensive banking sector efficiency analysis of sub Saharan African countries (SSA). The study employs two stage analyses in examination of profit efficiency and cost efficiency of commercial banks: stochastic frontier approach and Tobit regression. Stochastic frontier approach was utilized to estimate profit efficiency and cost efficiency, where asTobit regression was employed to provide cross country evidence of the influence of environmental factors on efficiency Sub Saharan African commercial banks, in similar vein the study intended to examine whether foreign banks are more efficient than domestic banks. The empirical results of the study indicated that foreign banks outperform domestic banks, which are consistent with the agency theory postulates; banks with higher leverage or lower equity are associated with higher profit efficiency. In terms of bank size, smaller banks were more profit efficiency where as medium size and larger banks are cost efficient. On another hand the findings of the study suggests that non SSA 
Foreign banks are more cost efficient than Sub Saharan foreign as well as domestic banks for the period of 20002003. Anne (2011) investigated the intermediation efficiency and productivity on banks in the period after liberalization of banking sector in Kenya, using Data Envelopment Analysis (DEA) approach. The results of the study indicated that, the banks were not fully efficient in all respects; however they performed fairly well during the period under study. Aikaeli (2008) examined commercial banks efficiency in Tanzania using data envelopment analysis (DEA) .The results indicated that, In terms of technical efficiency, foreign banks ranked the highest, followed by small banks and then large domestic banks; while regarding scale efficiency, small banks ranked the highest followed by international banks and then large domestic banks.

\subsection{METHODOLOGY}

Basically two approaches are available in the literature to assess bank efficiency, the stochastic efficiency frontier analysis and the deterministic frontier analysis. In the context of deterministic frontiers Data Envelopment Analysis (DEA) is by far the most used technique.

\subsection{Research approach}

In order to reach the objectives of this research the deductive approach was used, in view of the fact that there is much literature and theoretical framework on this topic. The construction of the research objectives itself insist on the utilization of the deductive approach.

\subsection{The choice of a model}

The Data Envelopment Analysis (DEA) approach was employed to distinguish the best practice banks group against which the relative performance efficiency of each bank will be derived using a numerical efficiency score and ranking.

The rationale for the researcher to opt this approach was, DEA differs from a simple efficiency ratio in that it accommodates multiple inputs and outputs and provides significant additional information about where efficiency improvements can be achieved and the magnitude of these potential improvements.

\subsection{Data Envelopment Analysis (DEA) model}

Data Envelopment Analysis (DEA) is a non-parametric mathematical programming approach to frontier estimation. DEA is approach that is considered as an alternative method to estimate productive efficiency in the financial sector. DEA approach shows how a particular bank operates relative to other banks in the same sample. It provides a benchmark for best practice technology based on the experience of those banks in the sample. The DEA estimates are based on technological efficiency where efficient firms are those for which no other firm (or linear combination of firms) produces as much or more of output provided given inputs, or uses as little or less input to produce a given output. The efficient frontier is composed of these un-dominated firms and the piecewise linear segment that connect the set of input/output combinations of these firms yielding a convex production possibility set (Humphrey at el, 1997).

In mathematical programming parlance, this ratio, which is to be maximized, forms the objective function for the particular DMU being evaluated. (Charnes, et al., 1978) proposed the use of a set of weights that accommodates those differences. The model is known as CCR model. They suggested that each bank should assign weights that allow it to be shown more favorably, compared with all other banks under comparison. Thus, the respective weights for each bank should be derived using the actual observed data instead of fixing in advance. The following fractional programming problem to obtain values for input weights and output weights.

\section{CCR Model}

$$
\max h_{o}(u, v)=\frac{\sum_{r=1}^{s} u_{r} y_{r o}}{\sum_{i=1}^{n} v_{i} x_{i o}}
$$

Subject to:

$$
\frac{\sum_{r=1}^{n} u_{r} y_{r j}}{\sum_{i=1}^{m} v_{i} x_{i j}} \leq 1
$$

$$
j=1,2 \ldots n
$$




$$
\begin{aligned}
& u_{r} \geq 0 \quad \mathrm{r}=1,2 \ldots \mathrm{s} \\
& v_{i} \geq 0 \mathrm{i}=1,2 \ldots \mathrm{m} .
\end{aligned}
$$

Where $x_{i j}$ is the observed amount of input ith of the jth DMU, $y_{i j}=$ observed amount of output of the rth type for the jth $\mathrm{DMU}, \mathrm{o}=1,2, \ldots, \mathrm{n}$.

The above ratio form yields an infinite number of solutions; if $\left(u^{*}, v^{*}\right)$ is optimal, then $\left(\alpha u^{*}, \alpha v^{*}\right)$ is also optimal for $\alpha>$ 0 . However, the transformation developed by Charnes and Cooper (1962) for linear fractional programming selects a representative solution [i.e., the solution $(u, v)$ for which $=1$ ] and yields the equivalent linear programming problem in which the change of variables from $(u, v)$ is a result of the Charnes-Cooper transformation one can select a representative solution $(u, v)$ for which:

$$
\sum_{i}^{m} v_{i} x_{i o}=1
$$

To obtain linear programming problem that is equivalent to linear fractional programme problem (equations 1 - 4). Thus, denominator in the above efficiency measure $h_{0}$ is set to equal to 1 and transformed linear problem for $D M U_{0}$ can be written as:

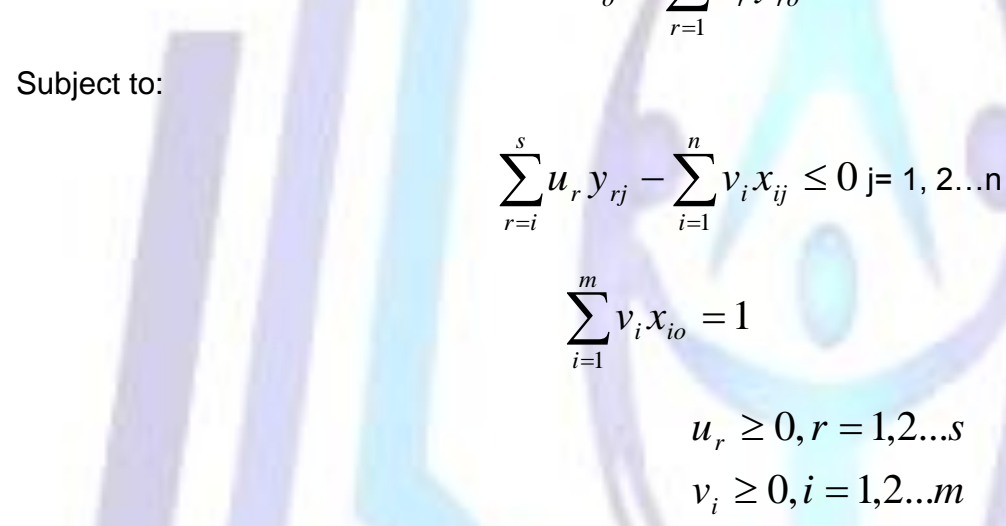

$$
\max z_{o}=\sum_{r=1}^{s} u_{r} y_{r o}
$$

For which the Linear Programming dual problem is

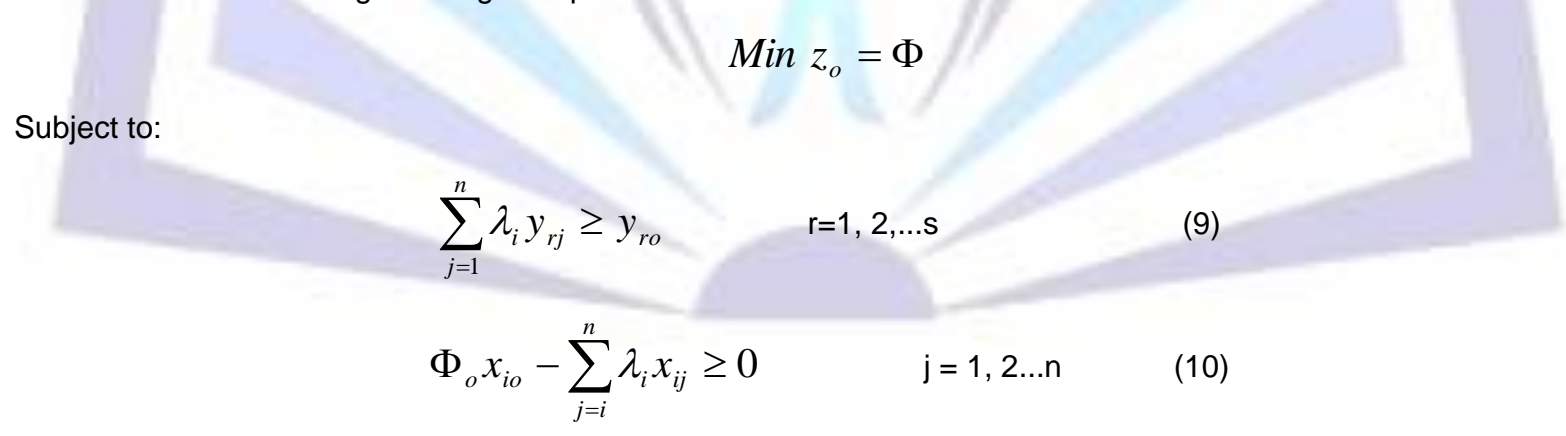

Both the above linear problem yield the optimal solution $\phi$ which is the efficiency score (so-called technical efficiency) for the particular $\mathrm{DMU}_{0}$ and repeating them for each $\mathrm{DMU}_{\mathrm{j}}, \mathrm{j}=1,2 \ldots \mathrm{n}$, efficiency scores for of them are obtained. The above $\phi$ is always less than or equal to unity (since when tested, each particular $\mathrm{DMU}_{0}$ is constrained by its own virtual input-output combination too). $\mathrm{DMU}_{\mathrm{s}}$ for which $\phi$ is less than unity are relatively inefficient and for which $\phi$ is equal to unity are relatively efficiency, having their virtual input-output combination points laying on the frontier. The frontier itself consists of linear facets spanned by efficient units of the data and the resulting frontier production function (obtained with the implicitly constant return to scale assumption) has no unknown parameters.

The CRS assumption is only appropriate when all DMUs are operating at an optimal scale, meaning that, one corresponding to the flat of the long run average cost (LRAC). However imperfect competitions, constraints on finance and other factors may result a DMU to be not operating at optimal scale. Banker, Charnes and Cooper (1984) suggest an extension of the CRS DEA model to account for Variable Return to Scale (VRS) situations. The use of the 
CRS specification when not all DMUs are operating at the optimal scale will result of TE which is confounded by scale efficiencies (SE). Hence, the use of the VRS specification will permit the calculation of TE devoid of these SE effects. The CRS linear programming problem can be easily modified to account for VRS by adding the convexity constraint $\sum \lambda=1$.

Since there are no constraints for the weight $\lambda_{\mathrm{j}}$, other than the positivity conditions in the problem $(9-10)$, it implies constant return to scale, it is necessary to add the convexity condition for the weight $\lambda_{\mathrm{j}}$. i.e. to include in the model $(9-$ 10) the constraint.

$$
\sum_{j=1}^{n} \lambda_{i}=1
$$

The resulting DEA model that exhibits the Variable Return to Scale (VRS) is called BCC model (Banker, Charnes and Cooper 1984). The input-oriented BCC model for the $\mathrm{DMU}_{0}$ can be written formally as:
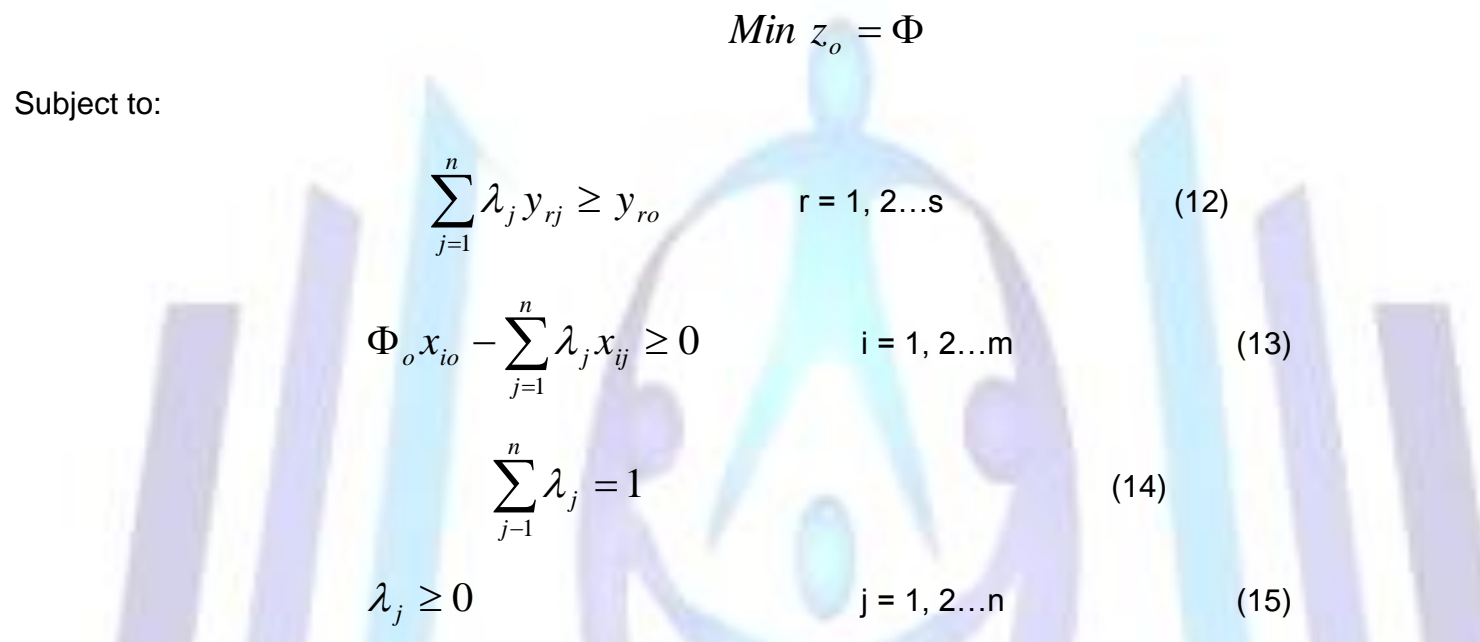

Running the above model for each DMU, the BCC efficiency scores are obtained (with similar interpretations of its values as in CCR model). These scores are also called 'Pure technical efficiency scores' since they are obtained from model that allows variable returns to scale (VRC) and hence eliminate 'the scale part' of the efficiency from analysis. Generally, for each DMU the CCR-efficiency score will not exceed the BCC efficiency score, what is intrusively clear since in the BCC-model each DMU is analyzed 'locally' i.e. compared to subset of DMUs, that operate in the same region of return to scale rather than globally.

\subsection{Defining Banking Inputs and Outputs}

The definition and identification of inputs and outputs to be used in banks efficiency for the purpose of measuring and examining the banks efficiency cannot be defined and specified in a simple way, it needs reasonable arguments (Favero and Papi 1995). In the literature, the inputs and outputs to be used in measuring of banks efficiency can be defined by using different five approaches: intermediation approach, production approach, asset approach, user cost approach and value added approach. The first three approaches are related to some functions carried out by the banks and the other two approaches are not related to the macroeconomic functions carried out by the banks (Favero and Papi 1995). The production approach and intermediation approach are used more frequently for measurement of the banking efficiency in banking sector. The production approach addresses physical inputs, such as capital and labor and treats a bank as firms producing different deposits and loan accounts. Banks deal with transactions and document for its customers who own these accounts. The number of accounts and transactions are regarded as the best measures of the bank output; to some extent this is not practical. In practice, the number of deposit and loan account is usually used as the measure of bank output rather than the detailed in transaction and documents (Ferrier and Lovell, 1990. The intermediation approach (Sealey and Lindley, 1997), treats banks as financial intermediaries that channels funds between depositors and creditors in the bank production process, the value of bank loans and investment is thought as output, while labor, deposits, total expenses and capital are treated as inputs.

\subsection{Selection of input and output variables}

By carefully examining the literature and the dominant role of intermediationfunction of banking sector in Tanzania we decided to follow intermediation approach on defining inputs and outputs for the analysis which was originally developed by Sealey and Lindley (1977) and commonly used by many authors. 
This study adopts Sealey and Lindley (1977) intermediation approach to specify the inputs and outputs that will be used in the empirical applications. Total Deposits, the number of employees and operating expenses are specified as three inputs whereas the outputs are loans and total interest income which are shown in table 1

Table: 1 Input-Output selection for DEA analysis

\begin{tabular}{|c|c|}
\hline Inputs & Outputs \\
\hline 1.Total deposits & 1. Total loans \\
\hline 2. Number of employees & 2. Total interest income \\
\hline 3. Operating expenses & \\
\hline Source: Study
\end{tabular}

\subsection{Data description and Population of the study}

The study used secondary data and the data was obtained from annual reports of the banks. Data were directly taken from the banks' balance sheets, income statements and from notes to account. Time study period is 7 years from 2006 to 2012; this period was selected because of reliable and up-to-financial data were available. Tanzania has a population of 45 institutions in the banking sector, includes 8 large banks, 19 medium banks, 14 regional \& small banks and 3 non-bank financial institutions (Bank of Tanzania 2011). The study was focused only in large commercial banks, all population of 8 large commercial banks were taken for the study. The rationale of selecting large commercial banks was made the sample of the study as homogeneous as possible, which is one of the requirement conditions of DEA approach. The study was comprised of 8 banks, which were analyzed from 2006 to 2012 , with a total of 56 pooled data.

\subsection{EMPIRICAL RESULTS AND ANALYSIS}

The analysis of efficiency of banking sector in Tanzania was done for the period of 7 years from 2006 to 2012 using the input-oriented DEA model. Both CCR and BCC models were applied for the analysis, we applied CCR model for a comparative purpose, because the model is completely ignores the scale of operations and may results to unrealistic benchmarks.

\subsection{Results of efficiency scores under CCR-Model}

Table 2 shows the CCR efficiency scores obtained by banks which were in operational from 2006 to 2012 , the results identify four banks, Barclays, Citibank, NBC and Standard Charted (50\%) to be fully efficient in the year 2006, and by fully efficient we mean the bank that has attained $100 \%$ efficiency score. while remaining four banks, CRDB, EXIM, NMB and Stanbic are inefficiency with efficiency scores of $75.2 \%, 88.7 \%, 83.2 \%$ and $76.1 \%$ respectively. Two banks, Citibank and Standard Charted were identified to be fully efficiency in 2007 and one bank, Citibank in 2008, 2009, 2010, 2011 and 2012. While The descriptive statistics results show that, the overall average efficiency for the banks is $83.7 \%$, which implies that the banks could have reduce the inputs by $16.3 \%$ without affecting the level of output. In other words, banks have wasted $16.3 \%$ of resources in producing their levels of output. The mean efficiency scores of banks in Tanzania ranges from $77.7 \%$ in 2010 to $90.4 \%$ in 2006 . In general the results show that banks are using more resources than what they are producing. Banks were supposed to use $83.7 \%$ of resources available for them to be efficient without compromising the output level under CRS.

Table 2 Efficiency scores results - CCR Model

\begin{tabular}{lllllllll}
\hline \multicolumn{1}{c}{ Bank } & $\mathbf{2 0 0 6}$ & $\mathbf{2 0 0 7}$ & $\mathbf{2 0 0 8}$ & $\mathbf{2 0 0 9}$ & $\mathbf{2 0 1 0}$ & $\mathbf{2 0 1 1}$ & $\mathbf{2 0 1 2}$ & Mean \\
\hline Barclays & 1.000 & 0.990 & 0.708 & 0.831 & 0.653 & 0.691 & 0.721 & 0.799 \\
Citibank & 1.000 & 1.000 & 1.000 & 1.000 & 1.000 & 1.000 & 1.000 & 1.000 \\
CRDB & 0.752 & 0.734 & 0.807 & 0.818 & 0.780 & 0.811 & 0.864 & 0.795 \\
EXIM & 0.887 & 0.767 & 0.741 & 0.770 & 0.795 & 0.824 & 0.857 & 0.806 \\
NBC & 1.000 & 0.821 & 0.832 & 0.922 & 0.755 & 0.654 & 0.685 & 0.810 \\
NMB & 0.832 & 0.767 & 0.868 & 0.835 & 0.663 & 0.828 & 0.858 & 0.807 \\
Standard Charted & 1.000 & 1.000 & 0.845 & 0.847 & 0.780 & 0.874 & 0.894 & 0.891 \\
Stanbic & 0.761 & 0.655 & 0.829 & 0.732 & 0.794 & 0.857 & 0.887 & 0.788 \\
\hline Overall Average & 0.904 & 0.842 & 0.829 & 0.845 & 0.777 & 0.817 & 0.846 & 0.837 \\
\hline
\end{tabular}


Source: Survey Study

Figure 1 shows the trend results of mean efficiency score of banks, on comparing the trends of efficiency scores for three consecutive years from 2006 to 2008, it can be clearly noticed that the efficiency of banks has decreased year after year from $90.4 \%$ in 2006 to $82.9 \%$ in 2008 , however the efficiency scores slightly started to increase from $77.7 \%$ in 2010 to $84.6 \%$ in 2012 .

Figure 1 Mean Efficiency Scores of Banks - CCR-Model 2006 -2012

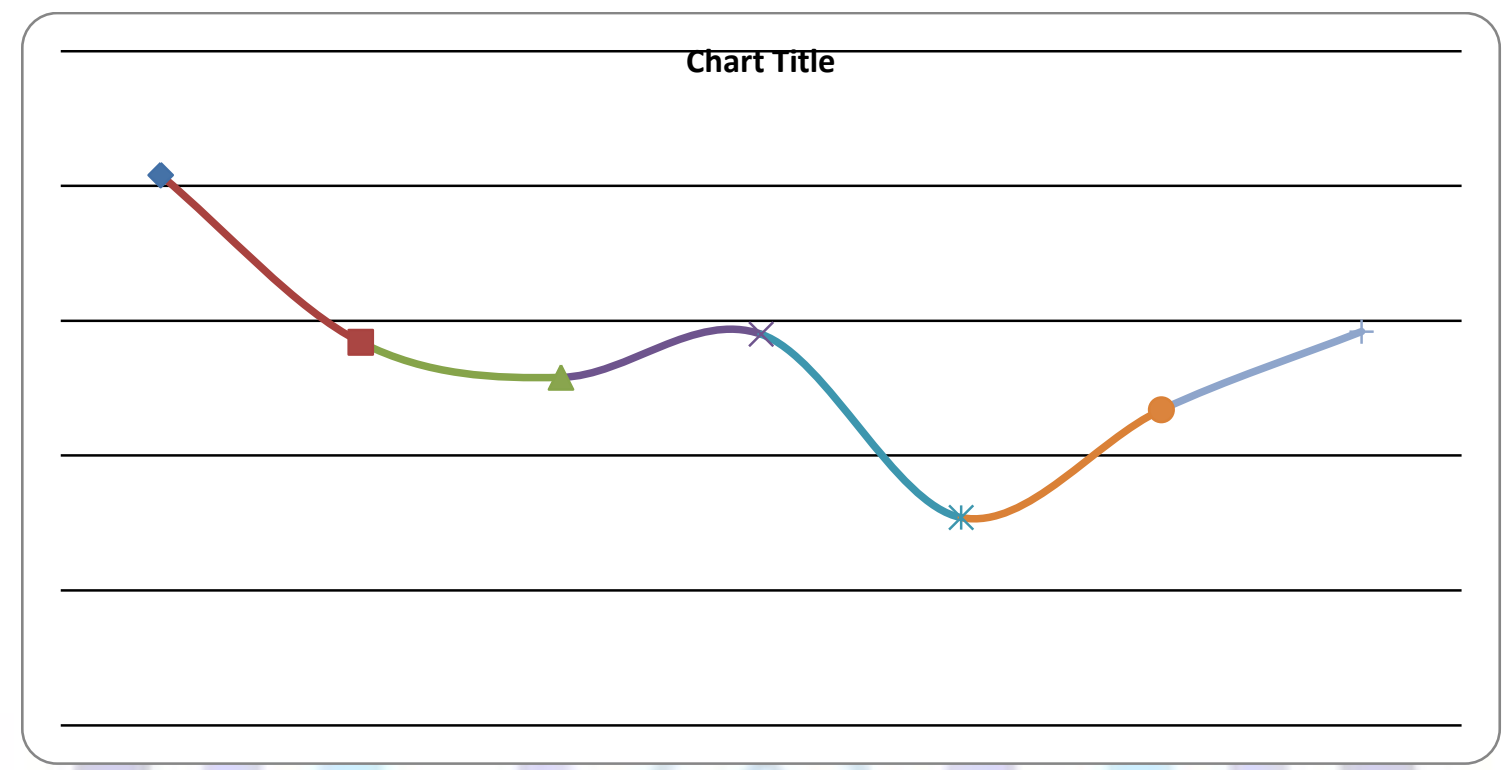

Source: Study Survey

\subsection{Results of Efficiency of Banks under BCC-Model}

Table 3 shows the BCC efficiency scores obtained by banks from 2006 to 2012, the results identify five banks Barclays, Citibank, NBC, EXIM and Standard Charted (62.5\%) to be fully efficient in the year 2006 and 2012 in which EXIM for 2006 and CRDB for 2012, three banks Barclays, Citibank, and Standard Charted in 2007 and two banks in 2008 and 2009, one bank, Citibank, 2010 and 2011; by fully efficient we mean the bank that has attained 100\% efficiency score. The results obtained are not surprising because the scores generated through CRS are less than or equal to the corresponding VRS scores (Banker et al, 1984).

Mean efficiency of banks under VRS ranges from to $94.4 \%$ in 2012 to $84.5 \%$ in 2010 while the overall average of efficiency is $90.2 \%$, this means that, banks could have reduced the inputs by $9.8 \%$ without affecting the level of output. In other words, banks have wasted $9.8 \%$ of resources in producing its levels of output. However the fluctuation on efficiency scores are marginally with the minimum efficiency score of $84.5 \%$ in 2010 and maximum efficiency score of $94.4 \%$ in 2012 .

Table 3 Efficiency scores results -BCC Model

\begin{tabular}{lllllllll}
\hline \multicolumn{1}{c}{ Banks } & $\mathbf{2 0 0 6}$ & $\mathbf{2 0 0 7}$ & $\mathbf{2 0 0 8}$ & $\mathbf{2 0 0 9}$ & $\mathbf{2 0 1 0}$ & $\mathbf{2 0 1 1}$ & $\mathbf{2 0 1 2}$ & Mean \\
\hline Barclays & 1.000 & 1.000 & 0.712 & 0.836 & 0.662 & 0.703 & 1.000 & 0.845 \\
Citibank & 1.000 & 1.000 & 1.000 & 1.000 & 1.000 & 1.000 & 1.000 & 1.000 \\
CRDB & 0.762 & 0.811 & 0.972 & 0.974 & 0.951 & 0.997 & 1.000 & 0.924 \\
EXIM & 1.000 & 0.867 & 0.777 & 0.784 & 0.796 & 0.827 & 0.828 & 0.840 \\
NBC & 1.000 & 0.838 & 0.933 & 1.000 & 0.880 & 0.835 & 0.854 & 0.906 \\
NMB & 0.834 & 0.819 & 1.000 & 0.985 & 0.793 & 0.993 & 1.000 & 0.918 \\
Standard Charted & 1.000 & 1.000 & 0.854 & 0.892 & 0.861 & 0.996 & 1.000 & 0.943 \\
Stanbic & 0.894 & 0.721 & 0.951 & 0.749 & 0.814 & 0.866 & 0.871 & 0.838 \\
\hline Overall Average & 0.936 & 0.882 & 0.900 & 0.903 & 0.845 & 0.902 & 0.944 & 0.902 \\
\hline Source: Survey Study & & & & & & & &
\end{tabular}


Figure 2 shows the mean efficiency scores trend of banks, on comparing the trends the results shows sharp decline of efficiency score from $90.3 \%$ in 2009 to $84.5 \%$ in 2010 , there after showing an increasing trend of efficiency score of $94.4 \%$ in 2012

Figure 2 Mean Efficiency Trends of Banks (BCC-Model) 2006 -2012

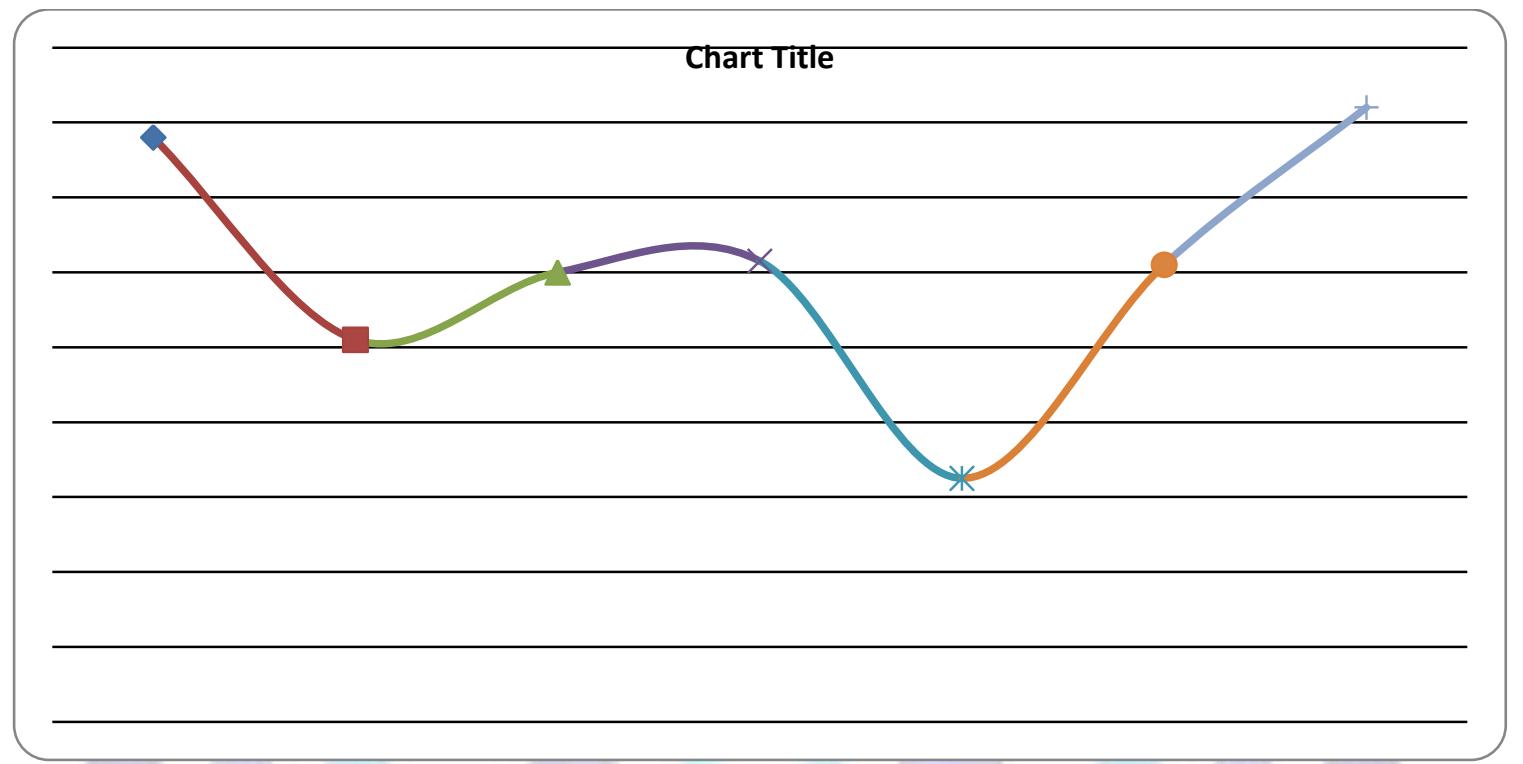

Source: Study Survey2013

\subsection{Identification of Reference set}

Table 4 shows the reference set for each bank obtained after BCC analysis. DEA approach being a widely used tool for benchmarking enables identification of efficiency DMU for inefficiency ones. This group of efficient DMUs when used for defining the operating procedures and goals for the inefficient units, in literature this group is being referred as peer group or reference set for the inefficiency DMU. The DMU which appears frequently on the reference set is considered to be a good example of efficiency performer. The results show that, four banks Standard Charted bank, National Commercial Bank (NBC), Citibank and Barclays bank are the most efficiency banks in Tanzania, because are frequently appeared on the reference set.

Table 4: Reference set BCC Model for the year 2006-2012

\begin{tabular}{|c|c|c|c|c|c|c|c|}
\hline Banks & 2006 & 2007 & 2008 & 2009 & 2010 & 2011 & 2012 \\
\hline Barclays & $\lambda 1=1$ & $\lambda 2=1$ & $\begin{array}{c}\lambda 1=0.70 \\
\lambda 29=0.04 \\
\lambda 43=0.19 \\
\lambda 44=0.07\end{array}$ & $\begin{aligned} \lambda 1 & =0.66 \\
\lambda 43 & =0.14\end{aligned}$ & $\begin{array}{l}\lambda 1=0.25 \\
\lambda 2=0.63\end{array}$ & $\begin{array}{c}\lambda 1=0.49 \\
\lambda 2=0.29 \\
\lambda 29=0.16\end{array}$ & $\lambda 7=1$ \\
\hline Citibank & $\lambda 8=1$ & $\lambda 9=1$ & $\lambda 10=1$ & $\lambda 11=1$ & $\lambda 12=1$ & $\lambda 13=1$ & $\lambda 14=1$ \\
\hline CRDB & $\begin{array}{l}\lambda 29=0.52 \\
\lambda 43=0.44\end{array}$ & $\begin{array}{l}\lambda 21=0.11 \\
\lambda 29=0.55 \\
\lambda 32=0.03 \\
\lambda 43=0.31\end{array}$ & $\begin{array}{l}\lambda 21=0.34 \\
\lambda 29=0.36 \\
\lambda 43=0.30\end{array}$ & $\begin{array}{l}\wedge 21=0.47, \\
\lambda 29=0.18 \\
\lambda 32=0.20 \\
\lambda 43=0.17 \\
\lambda 44=0.01\end{array}$ & $\begin{array}{l}\lambda 21=0.67 \\
\lambda 29=0.18 \\
\lambda 43=0.06 \\
\lambda 49=0.10\end{array}$ & $\begin{array}{l}\lambda 21=0.93 \\
\lambda 29=0.02 \\
\lambda 43=0.04 \\
\lambda 44=0.01\end{array}$ & $\lambda 21=1$ \\
\hline EXIM & $\lambda 22=1$ & $\begin{aligned} \lambda 1 & =0.08 \\
\lambda 2 & =0.13 \\
\lambda 10 & =0.77\end{aligned}$ & $\begin{aligned} \lambda 1 & =0.42 \\
\lambda 2 & =0.09 \\
\lambda 10 & =0.20\end{aligned}$ & $\begin{array}{c}\lambda 1=0.35 \\
\lambda 10=0.17 \\
\lambda 22=0.16\end{array}$ & $\begin{array}{c}\lambda 1=0.14 \\
\lambda 10=0.27 \\
\lambda 43=0.18\end{array}$ & $\begin{aligned} \lambda 1 & =0.15 \\
\lambda 43 & =0.40 \\
\lambda 44 & =0.21,\end{aligned}$ & $\begin{aligned} \lambda 1 & =0.07 \\
\lambda 29 & =0.29 \\
\lambda 43 & =0.46\end{aligned}$ \\
\hline
\end{tabular}




\begin{tabular}{|c|c|c|c|c|c|c|c|}
\hline & & & $\lambda 22=0.19$ & $\begin{array}{l}\lambda 29=0.15 \\
\lambda 44=0.16\end{array}$ & $\lambda 44=0.15$ & & $\lambda 44=0.19$ \\
\hline NBC & $\lambda 29=1$ & $\begin{aligned} \lambda 29 & =0.57 \\
\lambda 32 & =0.12 \\
\lambda 43 & =0.15, \\
\lambda 44 & =0.17\end{aligned}$ & $\begin{array}{l}\lambda 21=0.12 \\
\lambda 29=0.19 \\
\lambda 32=0.14 \\
\lambda 43=0.55\end{array}$ & $\lambda 32=1$ & $\begin{array}{l}\lambda 42=0.40 \\
\lambda 43=0.58\end{array}$ & $\begin{array}{l}\lambda 21=0.16 \\
\lambda 42=0.19 \\
\lambda 43=0.65\end{array}$ & $\begin{array}{l}\lambda 42=0.20 \\
\lambda 43=0.61\end{array}$ \\
\hline NMB & $\begin{aligned} \lambda 42 & =0.05 \\
\lambda 29 & =0.53, \\
\lambda 44 & =0.42\end{aligned}$ & $\begin{array}{l}\lambda 29=0.57, \\
\lambda 32=0.42 \\
\lambda 44=0.01\end{array}$ & $\lambda 38=1$ & $\begin{aligned} \lambda 32 & =0.19 \\
\lambda 38 & =0.42 \\
\lambda 42 & =0.39\end{aligned}$ & $\begin{aligned} \lambda 1 & =0.23 \\
\lambda 29 & =0.40 \\
\lambda 42 & =0.60\end{aligned}$ & $\begin{aligned} \lambda 32 & =0.10 \\
\lambda 38 & =0.01\end{aligned}$ & $\lambda 42=1$ \\
\hline $\begin{array}{l}\text { Standard } \\
\text { Charted }\end{array}$ & $\lambda 43=1$ & $\lambda 44=1$ & $\begin{array}{l}\lambda 11=0.14 \\
\lambda 29=0.19 \\
\lambda 43=0.63 \\
\lambda 49=0.05\end{array}$ & $\begin{aligned} \lambda 43 & =0.45, \\
\lambda 49 & =0.25\end{aligned}$ & $\begin{aligned} \lambda 29 & =0.04 \\
\lambda 43 & =0.13 \\
\lambda 49 & =0.51\end{aligned}$ & $\begin{array}{l}\lambda 11=0.06 \\
\lambda 43=0.02 \\
\lambda 49=0.92\end{array}$ & $\lambda 49=1$ \\
\hline Stanbic & $\begin{array}{c}\lambda 1=0.38 \\
\lambda 10=0.46, \\
\lambda 1=0.16\end{array}$ & $\begin{array}{l}\lambda 10=0.15, \\
\lambda 22=0.77 \\
\lambda 29=0.05, \\
\lambda 44=0.02\end{array}$ & $\begin{array}{l}\lambda 10=0.12 \\
\lambda 11=0.54 \\
\lambda 29=0.01 \\
\lambda 43=0.19\end{array}$ & $\begin{aligned} \lambda 1 & =0.34 \\
\lambda 11 & =0.46 \\
\lambda 29 & =0.19, \\
\lambda 43 & =0.01\end{aligned}$ & $\begin{aligned} \lambda 1 & =0.5, \\
\lambda 11 & =0.10, \\
\lambda 29 & =0.22 \\
\lambda 43 & =0.19\end{aligned}$ & $\begin{array}{l}\lambda 11=0.11 \\
\lambda 29=0.18 \\
\lambda 49=0.05\end{array}$ & $\begin{aligned} \lambda 11 & =0.05, \\
\lambda 29 & =0.19, \\
\lambda 43 & =0.68 \\
\lambda 42 & =0.08\end{aligned}$ \\
\hline
\end{tabular}

Source: Study Survey2013

In Table 5 shows the results of peer count summary of banks, which are obtained from table 4: The results show that, Standard Charted bank, National Commercial Bank (NBC), Citibank and Barclays bank have the highest peer counts in which Standard Charted bank rank first, followed by National Bank of Commerce (NBC) in the second place, Citibank in the third place and then Barclays bank in the fourth place. This means that the above mentioned banks are benchmarked by other peers. These banks are the most efficient, which serve as the benchmark peers for inefficient banks in the sample. Therefore, inefficient banks could improve their efficiency level by benchmarking efficient banks.

Table 5: Peer Count Summary of banks for period 2006-2012

\begin{tabular}{|c|l|c|c|c|c|c|c|c|}
\hline DMU & Banks & 2006 & 2007 & 2008 & 2009 & 2010 & 2011 & 2012 \\
\hline 1 & Barclays & 2 & 2 & 2 & 3 & 3 & 0 & 1 \\
\hline 2 & Citibank & 2 & 2 & 6 & 2 & 2 & 2 & 1 \\
\hline 3 & CRDB & 0 & 1 & 2 & 0 & 0 & 1 & 0 \\
\hline 4 & EXIM & 0 & 1 & 1 & 1 & 0 & 0 & 0 \\
\hline 5 & NBC & 3 & 7 & 6 & 5 & 4 & 4 & 2 \\
\hline 6 & NMB & 1 & 0 & 0 & 2 & 1 & 2 & 1 \\
\hline 7 & Standard Charted & 2 & 5 & 7 & 7 & 7 & 7 & 4 \\
\hline 8 & Stanbic & 0 & 0 & 0 & 0 & 0 & 0 & 0 \\
\hline
\end{tabular}

Source: Study Survey2013

\subsection{Tobit regression}

This section reports on our attempt to explain differences in the calculated efficiency scores of commercial banks after implementing Tobit model. We applied the Tobit regression model to determine drivers of efficiency, hence the model is used in order to gain an understanding of the contribution made by different selected variables, and this will help in focusing on the right areas of operations by identifying the efficiency drivers. In this study the Tobit regression model is used in order to clearly examine the determinants of efficiency, regressing the CCR and BCC efficiency scores obtained in table 2 and table 3 respectively as dependent variable. 
The Tobit regression model considering all the variables is represented as

$\theta_{i}=\alpha_{i}+\beta_{1}$ (Deposits) $+\beta_{2}$ (Number of Employees) $+\beta_{3}$ (Operating Expenses) $+\beta_{4}$ (Ioans) $+\beta_{5}$ (Interest income) $+\varepsilon_{i}$

Where, $\theta_{i}$ is the efficiency score for bank i computed from the CCR and BCC model

Deposits, Number of Employees and total expenses are inputs variables

Loans and Interest income are output variables

Table 6 and table 7 reports the results for the Tobit estimation for both CCR model and BCC model. It is important to note that the dependent variable in the model is the DEA efficiency score. A positive coefficient implies an efficiency increase whereas a negative coefficient means an association with an efficiency decline. The results of the regression are significant at $95 \%$ level of significance.

Table 6: Estimation results: Tobit model using BCC Efficiency Scores

\begin{tabular}{lcccc}
\hline Variables & Estimate & Std. Error & Z. Value & P Value \\
\hline (Intercept):1 & 0.9285500000 & 0.0233170000 & 39.8232 & \\
(Intercept):2 & -2.3588000000 & 0.1051300000 & -22.4363 & 0.209 \\
Deposits & 0.0000000968 & 0.0000000908 & 1.0663 & 0.000 \\
Employees & -0.0001950700 & 0.0000401960 & -4.8528 & 0.001 \\
Total Expenses & -0.0000049828 & 0.0000009558 & -5.2134 & 0.151 \\
Loans & -0.0000003031 & 0.0000001594 & -1.9015 & 0.000 \\
Interest Income & 0.0000071125 & 0.0000014789 & 4.8094 &
\end{tabular}

The Chi-Square test is 562.2 with six degree of freedom associated with P-value (0.000) obtained using CCR efficiency scores shows that the model is a good fit for the data

Table 7: Estimation results: Tobit model using BCC Efficiency Scores

\begin{tabular}{lcccc}
\hline \multicolumn{1}{c}{ Variables } & Estimate & Std. Error & Z. Value & P Value \\
\hline (Intercept):1 & 0.9284400000 & 0.0289100000 & 32.1145 & \\
(Intercept):2 & -2.2120000000 & 0.1177500000 & -18.7857 & 0.428 \\
Deposits & 0.0000001444 & 0.0000001112 & 1.298 & 0.000 \\
Employees & -0.0002292100 & 0.0000529090 & -4.3321 & 0.000 \\
Total Expenses & -0.0000041392 & 0.0000012010 & -3.4465 & 0.123 \\
Loans & -0.0000003630 & 0.0000001969 & -1.8435 & 0.000 \\
Interest Income & 0.0000081255 & 0.0000017783 & 4.5692 & \\
\hline
\end{tabular}

Source: Study Survey2013

In the case of BCC analysis the Chi-Square test is 422.6 with six degree of freedom associated with $\mathrm{P}$-value (0.000) obtained using CCR efficiency scores shows that the model is a good fit for the data

The results obtained using Tobit model shows that, number of employees, total expenses and interest income contribute significantly to the efficiency of commercial banks in Tanzania. The results show that, the number of employees and total expenses have negative constants meaning that these variables and banks efficiency have inverse relationship, this indicate that the efficiency of banks will fall by -0.0002292100 and -0.0000041392 for an increase of number of employee and total expenses respectively. However interest income has positive constant, meaning banks efficiency increase when interest income of banks increase, for an increase in interest income the efficiency of commercial banks will increase by 0.0000081255 . Referring the table 4 and 5 deposit and loans were found to e insignificant contributors to the efficiency. 


\section{CONCLUSIONS}

This paper evaluate the recent performance and assess the determinants of performance of commercial banks in Tanzania for the period from 2006 to 2012 using the input-oriented DEA model and Tobit regression model by utilizing case of large commercial banks. Three inputs (i.e. total deposits, number of employees and operating expenses) and two outputs (i.e. total loans and total interest income) specifications were used represent efficiency in intermediation process.

The findings, under CRS assumption identify four banks to be fully efficient in the year 2006, two banks in 2007 and one bank in 2008, 2009, 2010, 2011 and 2012, while the results under VRS assumption identify five banks to be fully efficient in the year 2006 and 2012, three banks in 2007 and two banks in 2008 and 2009, one bank 2010 and 2011. These findings are consistency with (Banker et al, 1984), because the scores generated through CRS are less than or equal to the corresponding VRS scores. The efficiency reference set results identify four banks are the most efficiency banks in Tanzania, in which peer count results of banks, show that, Standard Charted bank, National Commercial Bank (NBC), Citibank and Barclays bank have the highest peer counts whereby Standard Charted bank rank first, followed by National Bank of Commerce (NBC) in the second place, Citibank in the third place and then Barclays bank in the fourth place. Therefore, these banks are the most efficient, which serve as the benchmark peers for inefficient banks in the sample and comprise the best practice set or best practice frontier. For inefficient banks, inefficiency primarily comes from the revenue side, (output slacks (Revenues) > input slacks (Costs)). That is, the bank has non-zero slacks in generating revenues but it has very limited non-zero slacks in the usage of recourses (excess costs). Hence the managers of inefficiency banks should focus attention to these efficiency reference set which includes the banks against which each inefficient bank was found to be mostly directly inefficient. For these inefficiency banks to be efficiency, we recommend that, banks should minimize the use of input resources while maintaining the same level of output. By improved handling of operating expenses and by boosting banking investment operation, the less efficient banks can successfully endorse resource utilization efficiency and become efficiency one. In the general remarkable observation on commercial banks efficiency scores are that, banks in Tanzania are performing well. The overall mean efficiency score is not less than $85 \%$ at any one point these findings are similar with Aikaeli (2008). The efficiency of large banks in Tanzania is better because of the technological improvements and better managerial knowledge and experience. The results found that, there is marginally fluctuation on efficiency scores with the minimum efficiency score of $84.5 \%$ in 2010 and maximum efficiency score of $94.4 \%$ in 2012 . On comparing the trends of efficiency, there is sharp decline of efficiency scores from $90.3 \%$ in 2009 to $84.5 \%$ in 2010 ; the downward trend is attributable with the global financial crisis, thereafter there is an upward trend of efficiency to $94.4 \%$ in 2012.

The study applied a Tobit regression which offers useful economic insights. It is the discretionary variables that are acting as efficiency drivers. The results show that, the number of employees, operating expenses and interest income are the significant contributors in the efficiency of banks in Tanzania. Therefore for inefficient banks the managers should focus mainly on controlling the number of employees and operating expenses because these variables have negative sign and improving the interest income by proving highly performance loans and reducing the rate of nonperforming loans because this variable has positive sign. While loans and deposits variables have negative and positive signs respectively but they are insignificant.

\section{ACKNOWLEDGMENTS}

We would like to convey heartfelt thanks and appreciation to all those, who in one way or another, contributed to the successful completion of this paper. Sincere appreciation is extended to the reviewers of this paper for their constructive comments. Special thanks should also be extended to Director and Dean of Birla Institute of Management Technology, Prof. G. Mjema (Rector) of Institute of Finance Management Prof. G. Mjema and Prof. T Satta (Deputy Rector) of Institute of Finance Management for their continued support and encouragement. We would like also to put on record my sincere gratitude to those who have at different stages of this work been very encouraging and supportive

\section{REFERENCES}

[1] Aikaeli J. 2008 Commercial Banks Efficiency in Tanzaniall, Bank of Tanzania Monetary and Financial Affairs Department, A Paper Presented in a CSAE Conference on -Economic Development in Africall, Held at St. Catherine's College, Oxford, 16th - 18th March 2008.

[2] Kamau, A. 2011. Intermediation efficiency and productivity of the banking sector in Kenya' Interdisciplinary journal of research in business vol. 1, issue 9, (pp.12- 26)

[3] Bank of Tanzania. 2011. A Review of the Role and Functions of the Bank of Tanzania'

[4] Banker, R. D, Cooper, W. W, Seiford, L. M, Thrall, R. M and Zhu, J. 2004. Returns to Scale in Different DEA Modelsil, European Journal of Operational Research, vol. 154, no. 2, pp. 345-62. 
[5] Banker R, D. Charnes A, Cooper WW. 1984. Some Models for Estimating Technical and Scale Inefficiencies in Data Envelopment Analysis. Management Science 30: 1078-1092.

[6] Bauer et al. 1998. Consistency conditions for regulatory analysis of financial institutions: comparison of frontier methods. Journal of Business and finance, 50, 85-114

[7] Berger, A.N. and Humphrey, D.B. 1997. Efficiency of financial institutions: international survey and directions for future research', European Journal ofOperational Research 98(2): 175-212.

[8] Berger, A.N., Hunter, W.C and Timme, S.G. 1993. Efficiency of financial institutions .A review and preview of research, past present, and the future, Journal of banking and finance, 21,pp 895947

[9] Charnes, A, Cooper, W.W and Rhodes, E 1978. Measuring Efficiency of Decision Making Unitsll, European Journal of Operation Research, vol. 2, no. 6, and pp. 429-44

[10] Cooper, W. W., Seiford, L. M. and Kaoru, T. 2000. Data Envelopment Analysis; A comprehensive Text with Models, Application, References and DEA-Solver Software, Kluwer Academic Publishers, Boston

[11] European Investment Banks Report. 2013. Banking in sub-Saharan Africa Challenges and Opportunities

[12] Farrell, M. J. 1957. The Measurement of Productivity and Efficiencyll, Journal of the Royal Statistical Society (Series A- General), vol. 120, no. 2, pp. 253-81

[13] Favero C., Papi L. 1995. Technical and Scale Efficiency in the Italian Banking Sector: A Non-parametric Approach, Applied Economics, 27, 385-395

[14] Ferrier, G., Lovell, C.1990. Measuring cost efficiency in banking: Econometric and linear programming evidence. Journal of econometrics 46,229-245

[15] Grabowski, R., Rangan, N., and Rezvanian, R. 1994. The effect of deregulation on the efficiency of US banking firms", Journal of Economics and Business 46, 39-54

[16] Hempell H. 2002. Testing competition among the German banks' Discussion paper of the deutsche bundes bank

[17] Frimpong J. M. 2010 'Investigating Efficiency of Ghana Banks: A Non-Parametric' Approach American Journal of Scientific Research ISSN 1450-223X Issue 7 (2010), pp.64-76

[18] Nenovsky N, Chobanov P, Mihaylova G and Koleva D. 2008. 'Efficiency of the Bulgarian Banking System: Traditional Approach and Data Envelopment' Working paper series

[19] Noulas, A. 1997. Productivity growth in the Hellenic banking Industry: State versus private banks Applied financial Economics7 223-228

[20] OngTse San, Lim Yee Theng and Teh B.H. 2011. A Comparison on efficiency of Domestic and Foreign Banks in Malaysia: DEA approach, Journal of Business management Dynamics Vol 1 no 4,oct 2011,pp 349.

[21] Kent M and Mahadzir I. 2006, 'Efficiency and Productivity Growth of Domestic and Foreign Commercial Banks in Malaysia' Cardiff Economics Working Papers

[22] Kiyota A . 2009, Efficiency of commercial banks in Sub Sahara: A comparative analysis Domestic and Foreign bank, the paper presented at the CSAE conference 2009 on "Economic Development in Africa

[23] Pastor J., Perez, F. \& Quesada, J. 1997. 'Efficiency analysis in banking firms: An international comparison' .European Journal of Operational Research, 98, 395-407

[24] Sealey, C, W and Lindley, J, T. 1977. 'Inputs, Outputs, and a Theory of production and Cost of Depository financial Institutions' The Journal of finance 32

[25] SinkeyJr, Joseph F. 1992. Commercial bank financial management In: Financial-Service Industry, 4th Ed, Macmillan Publishing Company, Ontario

[26] Supachet, C. 2008. Relative efficiency of commercial banks in Thailand, DEA approach, International journal of Finance and Economics

[27] Wu, S. (2007), 'Efficiency and productivity analysis of the Australian banking sector under deregulation' PhD thesis, Department of Economics, The University of Melbourne

[28] Zuzana, I. 2009. 'Measuring Bank Efficiency' Master thesis, Institute of Economic Studies, Charles University in Prague 